\title{
Roes, retoriek en ratio : een sociaal epidemiologische standpuntbepaling ten aanzien van alcohol- en druggebruik
}

Citation for published version (APA):

Knibbe, R. A. (2001). Roes, retoriek en ratio : een sociaal epidemiologische standpuntbepaling ten aanzien van alcohol- en druggebruik. Maastricht University. https://doi.org/10.26481/spe.20011019rk

Document status and date:

Published: 19/10/2001

DOI:

10.26481/spe.20011019rk

Document Version:

Publisher's PDF, also known as Version of record

Please check the document version of this publication:

- A submitted manuscript is the version of the article upon submission and before peer-review. There can be important differences between the submitted version and the official published version of record.

People interested in the research are advised to contact the author for the final version of the publication, or visit the DOI to the publisher's website.

- The final author version and the galley proof are versions of the publication after peer review.

- The final published version features the final layout of the paper including the volume, issue and page numbers.

Link to publication

\footnotetext{
General rights rights.

- You may freely distribute the URL identifying the publication in the public portal. please follow below link for the End User Agreement:

www.umlib.nl/taverne-license

Take down policy

If you believe that this document breaches copyright please contact us at:

repository@maastrichtuniversity.nl

providing details and we will investigate your claim.
}

Copyright and moral rights for the publications made accessible in the public portal are retained by the authors and/or other copyright owners and it is a condition of accessing publications that users recognise and abide by the legal requirements associated with these

- Users may download and print one copy of any publication from the public portal for the purpose of private study or research.

- You may not further distribute the material or use it for any profit-making activity or commercial gain

If the publication is distributed under the terms of Article $25 \mathrm{fa}$ of the Dutch Copyright Act, indicated by the "Taverne" license above, 


\section{Roes, Retoriek en Ratio}

\section{Een sociaal epidemiologische standpuntbepaling ten aanzien van alcohol- en druggebruik}

Ronald A.Knibbe

Inaugurele rede

In verkorte vorm uitgesproken bij de aanvaarding van het ambt van Bijzonder Hoogleraar Sociale Epidemiologile Alcohol-en Druggebruik.

19 oktober 2001 
Ronald A. Knibbe

\section{Roes, Retoriek en Ratio}

Een sociaal epidemiologische standpuntbepaling ten aanzien van alcohol- en druggebruik

\section{Geachte toehoorders,}

Met de roes bent $u$ allen in meer of mindere mate vertrouwd. Ervan uitgaand dat hier een doorsnee van de Nederlandse bevolking zit, betreft dat voornamelijk een door alcoholgebruik opgewekte roes; slechts zo"n $10 \%$ tot $15 \%$ heeft ooit cannabis gebruikt; en het percentage dat ooit XTC, amfetaminen of cocailne, of heroine heeft gebruikt ligt zo laag dat wellicht niemand in deze zaal daar als gebruiker over mee kan praten. $U$ begrijpt wel dat ik 'roes' hier in brede zin opvat, inclusief de effecten bij matig gebruik.

Met de retoriek bent $u$, vooral waar het illegale drugs aangaat, waarschijnilikk ook vertrouwd. Er gaat bijna geen dag voorbij zonder dat het in het nieuws komt. En vrijwel altijd op een manier die duidelijk maakt hoe slecht en verdorven drugs, en alles wat daar mee te maken heeft, zijn. De maatschappelijke reactie op alcoholgebruik lijkt in eerste instantie meer op een enigszins fletse ideologische correctheid dan op volwaardige retoriek. Verslaving hoort niet, maar sociaal drinken is geen probleem, dat is zo ongeveer de boodschap. Echter in die ideologische correctheid zitten retorische elementen die op gespannen voet staan met een sociaal epidemiologische benadering van alcoholgebruik. I kom daar nog op terug.

De ratio in de titel van mijn rede wil ik reserveren voor de wetenschappelijke vragen en uitspraken over het gebruik van roesverwelkkende stoffen en well meer in het bijzonder de vragen betreffende primaire preventie: hoe misbruik te voorkomen; secondaire preventie: hoe verslechtering te voorkomen en hulpverlening.

I $\mathrm{k}$ begin met het omschrijven van het spanningsveld rond de roes. Daarna spits ik mijn betoog toe op twee onderwerpen: problematische hard drug gebruikers en alcoholgebruik. Bij beide onderwerpen zal ik de retoriek aan de orde stellen, aangeven welke wetenschappelijke vragen dat oproept en die vragen verder uitwerken. 


\section{Roes: een plaatsbepaling}

Bij alle verschillen in werking van roesverwekkende stoffen is er een gemeenschappelijk kenmerk: gebruik van deze middelen beinvloedt de beleving en de kwaliteit van ervaring van gebruikers. Die verandering in beleving, de roes dus, roept een principiêle vraag op waar geen enkele samenleving mensen volledig vrij laat hun eigen voorkeuren te volgen. Immers, de roes wordt zowel door de gebruiker als door nuchtere omstanders ervaren als anders dan het alledaagse bewustzijn. De roes staat in een gespannen verhouding tot het nuchtere bewustzijn dat nodig is om alle dagen weerkerende noodzakelijkheden het hoofd te bieden. Hierbij is te denken aan eten, drinken, onderdak, zorg voor kinderen, onderhouden relaties met partner, familie en dergelijke. Eeuwenlange ervaring met roesmiddelen leert dat na gebruik het cruciale belang van op tijd komen voor afspraken, vuilnisbakken buiten zetten, het huis poetsen wat meer gerelativeerd wordt. Kan het gebruik van roesmiddelen gecombineerd worden met de veelsoortige alledaagse verplichtingen jegens anderen? Dat is de vraag waar in iedere samenleving een antwoord op gegeven moet worden. Het antwoord vereist eensgezindheid van de betrokkenen. Velen kunnen zich geschaad voelen als iemand zijn roes belangrijker vindt dan zijn sociale verplichtingen.

In principe zijn er twee antwoorden mogelijk op de vraag of en zo ja hoe roesmiddelen gebruikt mogen worden: het fundamentalistische antwoord en het rekkelijke. In deze voordracht zal ik het gebruik van hard drugs als voorbeeld voor het fundamentalistisch antwoord nemen; het gebruik van alcohol voor het rekkelijke antwoord. Hoe interessant het ook zou zijn de rekkelijke en fundamentalistische benadering op cannabisgebruik en ander psychotrope stoffen toe te passen, de beperkte ruimte laat dat niet toe.

Het fundamentalistische antwoord is heel eenvoudig: met roesmiddelen wordt het bewustzijn gemanipuleerd. De ervaring is dus 'onecht'. Gebruik dient afgewezen te worden. Mensen die niet de verleiding van deze middelen kunnen of willen weerstaan zijn zwak en ziek en moeten zowel gestraft als geholpen worden.

Terzijde, het fundamentalistische antwoord behoeft geen afwijzing van de roes in te houden. De roes moet echter op eigen kracht, of dat nu marathonlopen is of derwisjdansen, bereikt worden. 
Het rekkelijke antwoord is niet een tegenovergestelde ideologie, waarin de voordelen breed uitgemeten worden. Het is een praxis, waarmee de vraag naar de "echtheid" van de opgewekte ervaring omzeild wordt. Die praxis is de ritualisering van het gebrulk. Het kan meer of minder collectieve rituelen betreffen in situaties die afgezonderd worden van het alledaagse leven. Cafébezoek, recepties en feesten zijn daar onder te rekenen. Ritualisering kan ook de vorm aannemen van meer individueel gekozen selectie aan situaties - de aperitief als men thuis komt van het werk, het glas wijn bij het eten, het slaapmutsje voor het slapen gaan. Ongeacht de vorm, het kenmerkende van ritualisering is dat het gebruik plaats vindt in een van het alledaagse leven afgegrensde situatie. In die situatie mogen mensen zich tijdelijk onttrekken aan de verplichtingen van het alledaagse leven. Dat geldt ook voor de verplichting een rationeel antwoord te geven op de vraag hoe 'echt' die door roesmiddelen opgewekte ervaring nu wel is. Voor de duur van een drinksituatie mag de gebruiker doof zijn voor iedere meer reflexieve of kritische bejegening van zijn of haar gebruik en, minstens zo belangrijk, mag verwachten dat anderen zich aan die spelregel houden. Maar die doofheid voor meer kritische geluiden is opgeheven buiten de drinksituatie. Dan is ook duidelijk dat drankgebruik van sommigen hun functioneren in het alledaagse leven schaadt, hetzi] incidenteel, b.v. door een kater, tremoren, hetzij chronisch, b.v. door leverschade of een Korsakow -syndroom. De ritualisering die hoort bij het rekkelijke antwoord, vereist wel een idee waarom drankgebrulk tot ontsporingen leidt die wel degelijk aan de drinker en zijn sociale omgeving schade berokkent. Bij de in een samenleving dominante ideeën daarover ligt het begin van retoriek rond alcoholgebruik.

\section{Retoriek rond illegale drugs}

IK leg u enkele citaten voor uit een vergadering van de "Commission of Narcotic Drugs" van de Verenigde Naties. Het betreft een vergadering uit 1997. Bij aanvang van de vergadering is er ruimte voor alle 54 deelnemende landen een positieverklaring af te geven. Hoe wordt het probleem beschreven door de vertegenwoordigers van landen?

- "The drug problem is a monster ensnaring the whole planet in its tentacles" (Wit Rusland)

- "Drugs are scourges which threaten the very basis of our living" (Uruguay). 
De taal doet enigszins deniken aan de wijze waarop in jongensboeken gevaren breed en bloemrijk uitgemeten worden. Het vervolg stelt niet teleur in termen van jongensboeken. Moed houden, ook in het aangezicht van een overweldigende vijand, is de enige juiste houding.

- "We use warlike language, but the war on drugs is about to be lost, if not already lost according to some. So we need a nondefeatist line" (France)

Alle jongensboeken zullen er ook op wijzen dat geneigdheild tot compromissen uit lafheid geboren worden.

- "The calls for a policy of despair, like legislation, come from the recognition that drug policy don't work" (U.K.)

- "The US cannot embrace "harm reduction" as a goal. It connotes a tacit acceptance of drug abuse, and becomes a de-facto decriminalisation." (USA)

Ik kan nog lang doorgaan met citeren, maar het zal u wel duidelijk zijn dat hier sprake is van een niet mis te verstane retoriek en grote eensgezindheid tussen alle landen. Die eensgezindheid betreft voor alles dat bij illegale drugs het fundamentalistische antwoord, dat wil zeggen straffen, het primaat dient te hebben. Op de zeldzame uitzondering hierop kom ik straks nog.

De meer wetenschappelijk geïnspireerde vraag is natuurlijk: helpt dat nu, dat verbieden en straffen? En, gesteld dat verbod en bestraffing niet voldoende zijn: hoe moet omgegaan worden met de mensen die toch deze middelen gebruiken? Op beide vragen zal ik ingaan.

\section{Gebruik van hard drugs}

Verbieden en straffen: hoeveel helpt dat?

Om te weten of verboden helpen, moet het aantal druggebruikers geteld kunnen worden en dat is een probleem. Gebruikers van verboden middelen laten zich niet zo gemakkelijk tellen. Vanwege: de straffen die er op staan hebben ze de neiging hun gebruik te verbergen, ook voor onderzoekers met de beste intenties. Het verborgene van gebruik omzeil ik ten dele door me te concentreren op de caltegorie gemarginaliseerde illegale druggebruikers. Het is de categorie waar langdurig frequent druggebruik gepaard gaat met medische, psychologische en sociale problemen. Vanwege deze problemen is dan ook een deel van deze groep gebruikers bekend bij de politie of hulpverlening. Door die 
registraties te gebruiken en aannames te doen over welk deel niet bekend is bij politie of hulpverlening, kan de totale omvang geschat wonden. Zo wordt het in de meeste landen gedaan. Een betere manier is echter gebruikers in hun natuurlijke omgeving opzoeken, een steekproef interviewen, o.a. over hun sociale netwerk en op basis daarvan een omvangschatting maken. Zo wordt het gedaan in onderzoeken waar het Instituut voor Onderzoek naar Leefwijze en Verslaving (IVO) bij betrokken is.

Een heel ander probleem voor de onderzoeker is de grote internationale eensgezindheid dat druggebruik gestraft dient te worden. Als druggebruikers overal in dezelfde mate vervolgd worden, kan natuuriijk niet nagegaan worden of minder straffen nu tot een hoger percentage druggebruikers leidt. Dat probleem omzeil ik door de uitzondering op die internationale eensgezindheid bij mijn verhaal te betrekken: Nederland.

Wellicht herinnert $u$ zich nog de kwalificatie van de Britse afgevaardigde van legalisatie als een 'policy of despair', oftewel "wanhoopsbeleid"? Hij bedoelde het Nederlandse drugs beleid. Wellicht herinnerde $\mathrm{u}$ zich de oproep van de Franse afgevaardigde voor een "non defeatist line", d.w.z. miet gedogen en de Amerikaanse veroordeling van het beleid van 'harm reduction" d.w.z. schadebeperking, als acceptatie van drugsmisbruik? Beide opmerkingen waren gericht tegen het Nederlandse drugsbeleid. Nederland onderscheidt zich internationaal door de combinatie van minder sterke criminalisering van druggebruikers en meer programma's gericht op beperking van gezondheidsschade bij gebruikers. Heeft dit gedoogbeleid geresulteerd in een in Nederland hogere prevalentie van problematische druggebruikers? Nee, daar lijkt het niet op. Vanwege de vergelijkbaarheid in schattingen presenteer ik slechts voor enkele Europese landen cijfers.

Prevalentie gemarginaliseerde druggebruikers in enkele Europese landen

\begin{tabular}{|l|r|r|}
\hline Land & aantal absoluut & per $100015-54$ jarigen \\
\hline Denemarken & 12.500 & 4.2 \\
\hline Duitsland & $100.000-150.000$ & $2.2-2.3$ \\
\hline Frankrijk & 160.000 & 5.0 \\
\hline Nederland & $25.000-28.000$ & $2.7-3.1$ \\
\hline Zweden & $14.000-20.000$ & $3.0-4.3$ \\
\hline
\end{tabular}

Bron: Annual Report of the state of the drug problems in the European Union. EMCDDA, 1998 
In Nederland is de prevalentie nauwelijks hoger dan in bv. Duitsland. in landen die zich kenmerken door een heel actief strafbeleid tegen druggebruikers, Frankrijk en Zweden b. $v_{x,}$ is de prevalentle bepaald niet lager dan in Nederland.

Het antwoord op de vraag of minder straf en uitgebreidere hulpverening tot een hoger aantal problematische drug gebruikers leidt is duidelijk: nee dat doet het niet.

De tweede vraag was: wat gebeurt er nu met langdurige gebruikers van illegale drugs, behalve ze korter of langer opsluiten in de gevangenis?

In vrijwel alle landen van Europa en Noord Amerika is er ook een aanbod aan hulpverlening specifiek gericht op druggebruikers. Dit hulpverleningsaanbod is er op gericht gebruikers te helpen stoppen met gebruik. De gemeenschappelijke ervaring van alle landen met behandeling gericht op stoppen met gebruik is (a) dat een groot deel van de mensen die aan de behandeling beginnen, die niet afmaken (b) een groot deel na voltooien van de behandeling weer begint met gebruik en (c) vanuit therapeutisch standpunt de zogeheten 'motivatie' van gebruikers om te stoppen vaak niet te best is. Een medisch aanbod gericht op stoppen met gebruik is slechts beperkt effectief in het terugdringen van het aantal problematische gebruikers. Voor de grote groep die overblijft doet dat de vraag naar secondaire preventie of, "harm reduction", opkomen. Als gevangenis en hulpverlening slechts zeer beperkt helpt om druggebruik te stoppen, kan dan wellicht de schade ten gevolge van het gebruik gestopt worden? Het is een redelijke vraag, maar ik heb reeds aangegeven hoe deze vraag in het internationale forum beantwoord wordt. Schadebeperkende maatregelen zijn alleen mogelijk als druggebruik uit de criminele sfeer wordt getrokken. Het is immers onwaarschijnlijk dat voorzieningen als spuitomruil, dagopvang voor druggebruikers en gebruiksruimtes goed werken als er een politie agent bij staat. Nu is, ondanks alle retoriek, in alle landen het aantal voorzieningen gericht op schadebeperking bij druggebruikers toegenomen sinds de Aids epidemie. Desalniettemin er zljn nog steeds verschillen in drugsbeleid tussen Nederland en andere landen.

Ik will wat resultaten uit een kleinschalige studie presenteren om duidelijk te maken waartoe verschillen in drugsbeleid leiden voor de druggebruikers zelf en voor de hulpverleners. Het is een studie uitgevoerd door Saskia Junger onder mijn supervisie en met medewerking van het CAD-Limburg. Het bijzondere van deze 
studie is dat de druggebruikers en hun hulpverleners woonden en werkten in een gebied van omstreeks viffig vierkante kilometer waar een grens door loopt: de grens tussen Nederland en Duitsland. Druggebruikers die in b.v. Aken woonden, en hun hulpverleners, werden ondervraagd en nog geen 15 kilometer naar het westen gebeurde hetzelfde in Heerlen in Nederland. De focus op een klein geografisch gebled waar een grens door loopt geeft grote zekerheid dat de verschillen tussen druggebruikers en hulpverleners het gevolg zijn van verschillen in beleid. De studie is kleinschalig wat betekent dat er slechts 25 Duitse en 25 Nederlandse druggebruikers ondervraagd werden. Tevens 25 Duitse en 25 Nederlandse hulpverleners. De verschillen tussen Duitsland en Nederland in het hiernavolgende zijn echter allen statistisch significant.

$\mathrm{lk}$ begin met de verschillen in justitieel beleid. In Duitsland was het beleid om druggebruikers in de gevangenis te zetten als ze gebruikten of drugs in bezit hadden. In Nederland waren beide feiten ook strafbaar, maar was en is het beleid om geen vervolging in te stellen, tenzij iemand ook handelt in drugs. Dit verschil in beleid komt duidelijk naar voren. De Nederlandse en Duitse druggebruikers kwamen overeen in leeftijd waarop begonnen werd met heroïnegebruik en leeftijd ten tijde van interview. De Duitse druggebruikers hadden echter gemiddeld 34.5 maanden in de gevangenis gezeten, de Nederlandse druggebruikers 12.8 maanden. Dit verschil in tijd doorgebracht in de gevangenis kwam niet doordat Duitse druggebruikers vaker stelen of geweld piegen. Het komt doordat ze vaker vanwege druggebruik in de gevangenis gezet zijn.

Hoe weet ik dat zo zeker? De druggebruikers zijn geworven bij het meest laagdrempelige hulpverleningsprogramma in Duitsland en Nederland: methadon programma"s. Aan de Duitse deelnemers aan het methadonprogramma worden echter zwaardere eisen gesteld. Conform het officiële drugsbeleid, was in Duitsland voorwaarde voor deelname aan het methadonprogramma de intentie om het druggebruik te stoppen. In Nederland is dat geen eis. In Duitsland is een reden voor verwijdering uit het programma crimineel gedrag. Daartoe behoorde ook druggebruik en daarop werd dan ook gecontroleerd middeis o.a. urine controles. In Nederland is gebruik van drugs geen reden voor verwijdering uit het methadon onderhoudsprogramma. De enige criteria in Nederland voor verwijdering uit het programma, gelden ook in Duitsland: niet op komen dagen bij de verstrekking van methadon 
en handel in drugs of gewelddadig gedrag tijdens verstrekking. Omdat het Nederlandse methadon programma minder selectief is dan het Duitse is te verwachten dat -als er al verschillen zijn in geweldsmisdrijven en diefstal- de Nederlandse methadon cliënten zich daar vaker schuldig aan maken.

De geringere selectiviteit van Nederlandse programma's blijkt ook uit het feit dat Nederlandse methadon cliênten meer geld per maand uitgeven aan drugs en drank (fl. 1067,, ) dan Duitse gebruikers (f1. $314_{1}-$ ) en het aantal dagen dat ze de maand voorafgaand aan het interview last hadden van problemen vanwege druggebruik (24 vs. 17 dagen). Samenvattend kan gesteld worden dat het bereik van methadonprogramma's in Nederland waarschijnlijk hoger is. De effectiviteit in het verminderen van gebruik en van daarmee samenhangende problemen is echter geringer in Nederland.

Als het gaat om overlleven is de Nederlandse druggebruiker echter duidelijk beter af dan de Duitse. Uit de studie blijkt dat door het verschil in frekwentie van overdoses, een belangrijke doodsoorzaak bij druggebruikers. De Duitse druggebruikers meiden gedurende hun carrière als druggebruiker gemiddeld bijna 2 keer (1.78) zo vaak geleden te hebben onder een overdoses dan de Nederlandse gebruikers $(0.95 ; p<0.10)$. Als het gaat om het aantal drugsdoden moet ik de context van deze studie verlaten en cijfers gebruiken die voor heel Nederland en Duitsland gelden. In Duitsland was in 1995 het absolute aantal drugsdoden ruim 45 keer hoger dan in Nederland (1565 vs. 33; EMCDDA, 1998; zie ook EMCDDA, 2001 voor meer gedetailleerde vergelijkingen). Het absolute aantal problematische druggebruikers is naar schatting 4 tot 6 keer hoger in Duitsland. Bij alle onzekerheden in internationale vergelijkingen, is er toch duidelijk een conclusie te trekken. Gebruikers hebben in Nederland een betere kans op overleven dan in Duitsland.

Vanuit de druggebruiker gezien heeft het Nederlandse beleid als voordeel dat ze minder tijd in de gevangenis doorbrengen, ze aan minder eisen hoeven te voldoen om deel te nemen aan hulpverleningsprogramma's en grotere bescherming ondervinden tegen overdoses en dood wegens druggebruik. Allemaal positief te waarderen zaken. Je zou dan ook verwachten dat Nederlandse druggebruikers redelijk tevreden zijn over de hulpverlening en Duitse druggebruikers wat meer verbitterd zijn over de tekort- 
koming van de hulpverlening. Dat is echter niet zo. Nederlandse drugsverslaafden zijn vergeleken met de Duitse verslaafden

- vaker ontevreden over de frequentie van contact ( $28 \%$ vs. $0 \%$ )

- vaker ontevreden over de houding van de hulpverleners (24\% vs. $4 \%$ zeer slecht/twijfelachtig)

- ontevreden over de organisatie van de methadonverstrekking ( $40 \%$ vs. $8 \%$ behoefte aan verandering)

Bij de interpretatie van dit verschil wil ik beginnen bij de tevredenheid van de Duitse druggebruiker. Als hulpverlener in Duitsland heb je een gebruiker tegenover je zitten die gemiddeld drie jaar onderwerp is geweest van de strikte dwang en drang die er in gevangenissen heerst. Het is duidelijk -anders zou de druggebruiker niet tegenover de hulpveriener zitten- dat dit niet heeft geholpen. De hulpverlener zal daarom waarschijnlijk maximale afstand houden van alle dwang en drang. Hij zal wel proberen zo goed mogelijk aan te sluiten bij de noden en wensen van de gebruiker. Natuurlijk zijn daar beperkingen aan, o.a. de vergelijkenderwijs strenge programma-eisen, en het justitieel beleid in Duitsland. Echter, dat zal de gebruiker de hulpverlener niet snel kwalijk nemen. Vergelijk daarmee de Nederlandse situlatie. Er is geen politie en justitie en beperkende programma voorwaarden die als onzichtbare derden dwang en drang uitoefenen op de gebruiker. Er wordt hulp verleend, echter die bestaat voor het grootste deel van de druggebruikers uit een vrijwel dagelijkse gang naar de methadonverstrekking, een middel dat minstens zo verslavend is als heroine. Tijd voor meer psychosociale hulpverlening is er nauwelijks of niet. Hoewel de verstrekkers ook

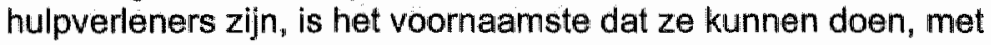
enige goed bedoelde dwang en drang cliënten voor grotere rampspoed pogen te behoeden. De directeur van de verslavingszorg in Rotterdam, de heer Czyzewki, heeft de methadonverstrekking terecht getypeerd als het Siberië van hulpverleningsland. Niet omdat de hulpverleners niet hun best doen. Wel omdat het een aanbod is dat veel nadruk legt op een uniform farmacologisch regime. Niet aandacht voor, maar controle van de druggebruikers staat centraal.

Het verschil tussen Duitse en Nederlandse hulpverleners in controleren van hun cliénten komt dan ook duidelijk naar voren in de mate waarin hulpverleners dwang en drang gebruiken.

Het begint al met verwijzingen door politie of justitie van druggebruikers: $48 \%$ van de Duitse hulpverleners vindt verwijzing door 
de politie of rechtbank geen goede basis voor behandeling. In Nederlands is dat slechts $10 \%$.

Veelbetekenend is ook het verschil in de omgang met dringende behoeften van de client. De helft $(47 \%)$ van de Nederlandse hulpverleners zegt niet in te gaan op dringende behoeften van cliënten. In Duitsland zegt slechts $5 \%$ van de hulpverleners daar niet op in te gaan. Als het gaat om het gebruik van drang en dwang in de hulpverleningssitulatie rapporteert bijna driekwart $(71 \%)$ van de Nederlandse hulpverteners dat ze directief optreden. In Duitsland rapporteert slechts $17 \%$ van de hulpverleners directief op te treden. Tenslotte, slechts $5 \%$ van de Nederlandse hulpverleners zegt geen drang te gebruiken bij de behandeling. In Duitsland is dat $44 \%$ van de hulpverleners. Kortom, de Nederlandse hulpverlener in de methadonprogramma's kenmerkt zich door een veel grotere bereidheid dwang en drang ook in de hulpverleningssituatie te gebruiken. Deze conclusie kan algemener geformuleerd worden: een beleid van 'harm reduction' en decriminalisatie vereist een sterkere toepassing van dwang en drang in hulpverleningssituaties. Bij alle enthousiasme in de internationale hulpverleningswereld voor het zogeheten Nederlandse model, wordt dit aspect meestal niet genoemd. Ja 'harm reduction' werkt als de overlevingskans van verslaafden als uitgangspunt genomen wordt; nee de verslaafden zelf zijn er minder tevreden mee dan met hulpverleners die zich onthouden van dwang en drang en voor de hulpverleners zelf is het ook niet altijd even dankbaar werk.

Het is duidelijk dat de toekomst ligt in een benadering waarin veel minder controle van gebruikers centraal staat. Juist de systematische verschillen in noden en behoeften bij druggebruikers die niet kunnen of willen stoppen dienen het uitgangspunt te zijn voor een hulpverleningsaanbod. Met het ontwikkelcentrum sociale verslavingszorg hebben de verslavingsinstellingen in Nederland het initiatief genomen om instrumenten en voorzieningen te ontwikkelen die ook zullen leiden tot een grotere differentiatie in hulpaanbod. Daarbij speelt onderzoek van de Universiteit Maastricht en het IVO een rol Ik verwacht met dat onderzoek te kunnen bijdragen aan verbetering van de kwaliteit van bestaan van chronische druggebruikers. 


\section{Retoriek rond alcoholgebruik}

Het aantal doden en zieken ten gevolige van alcoholgebruik is vele malen groter dan door druggebruik. De retoriek rond alcohol is echter veel minder luidruchtig. Een eeuw geleden was dat wel anders in de meeste westerse landen. Toen woedde er een zware strijd tussen de fundamentalisten, die drank geheel en al wilden verbieden en de rekkelijken die een verbod te ver vonden gaan. Het is meestal met enige nostalgie, maar ook met enig superioriteitsbesef, dat we terugkijken naar de strijd van de geheelonthoudersbewegingen. Verbieden van drank wordt niet meer als oplossing gezien. Een rekkelijke houding domineert en is de achtergrond van de ideologische correctheid die op maatschappelijk niveau rond alcoholgebruik heerst. Twee belangrijke elementen in deze ideologische correctheid zijn (1) dat iedereen in de eerste plaats zelf verantwoordelijk is voor zijn drankgebruik en (2) sociaal drinken mag, maar excessief drinken is onverantwoord. In de rekkelijke benadering wordt er van uitgegaan dat, op een klein aantal uitzonderingen na, iedereen de verantwoordelijkheid aan kan om drank niet te misbruiken. Wat er nu precies aan de hand is met die uitzonderingen is aan de wetenschap om uit te zoeken. Maar die zelfde wetenschap moet geen probleem gaan maken van de sociaal geaccepteerde en gangbare drinkgewoonten want daar ligt, als de rekkelijke redenering gevolgd wordt, in ieder geval niet het probleem. Wat echter als uit diezelfde wetenschap naar voren komt dat er een sterk verband is tussen de in een samenleving gangbare drinkgewoonten en de mate waarin er excessief wordt gedronken? Tegenover de rekkelijke ideologie dat de gangbare drinkgewoonten geen probleem zijn, kan een andere stelling gezet worden: de gangbare drinkgewoonten in een samenleving bepalen in sterke mate de mate waarin er excessief drankgebruik voorkomt.

Een ander problematisch punt in de rekkelijke benadering betreft de ritualisering van drankgebruik Zoals gezegd, betekent dit dat voor de duur van een drinksituatie drinkers vrijgesteld zijn van de verplichting hun drinkgedrag te verantwoorden. Maar die vrijstelling verdraagt zich slecht met de norm van 'eigen verantwoordelijkheid voor drankgebruik'. Er is hier een onophefbaar spanningsveld tussen de ideologie dat iedereen persoonlijk verantwoordelijk is voor zijn of haar drankgebruik en de praxis dat jedereen in drinksituaties juist even vrijgesteld wordt van die persoonlijke verantwoordelijkheid. Hier ligt dan ook de blinde vlek 
van de rekkelijke benadering. Die blinde wek wil ik zichtbaar maken met de volgende stelling: er zijn maatschappelijke geaccepteerde drinksituaties waarin alcoholmisbruik een collectief verschijnsel is.

\section{Gangbaar drankgebruik en excessief drankgebruik}

Met betrekking tot drugs is er een wet- en regelgeving om burgers geheel en al van druggebruik te weerhouden. Bij alcoholhoudende dranken is het bijna omgekeerd. Er zijn wetten over de minimum leeftijd voor werkoop van alcoholische dranken (16 jaar voor zwak alcoholische dranken en 18 jaar voor sterk alcoholische dranken) en over de maximale toegestane alcoholgehalte in het bloed bij verkeersdeelname. Maar daarmee heb je het ongeveer wel gehad. Waartoe dit minimum aan beperkende maatregelen kan leiden is uit deze grafiek af te lezen.

Het gemiddelde alcoholgebruik door Nederlanders van 14 jaar en ouder over de periode 1870-1980

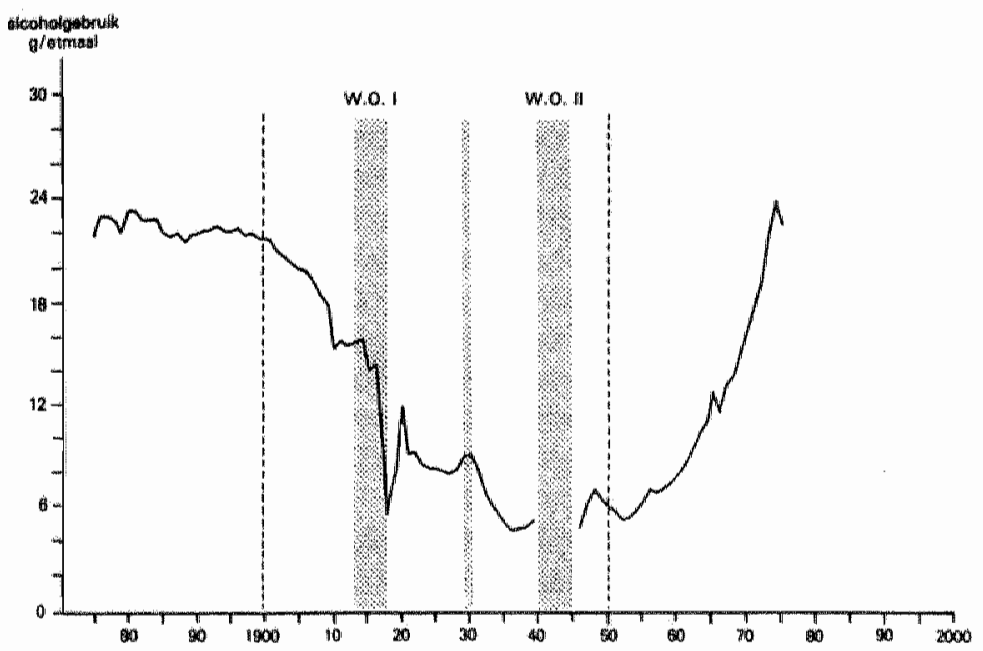

De gemiddelde consumptie fluctueert sterk per historische periode. Anno 2001 drinken we lets meer dan in 1900. In het grootste deel van de tussenliggende periode was de consumptie echter lager. Nu is er, anders dan in 1900 geen grote steun voor wetteligke beperkingen van alcoholgebruik en ook wordt alcohol- 
gebruik nu in veel mindere mate geassocieerd met maatschappelijke verval en verloedering.

Ik wil me concentreren op de periode na de $2^{\ominus}$ wereldoorlog, meer in het bijzonder de periode na 1960. In Nederland verdrievoudigde de gemiddelde alcoholconsumptie tussen 1960 en 1980. Daarna is de gemiddelde consumptie blj benadering stabiel gebleven. Hoewel in de meeste andere Europese landen de consumptie ook steeg vanaf 1960 was in Nederland de stijging sterker dan in de andere landen. Ik zal vanuit twee perspectieven op deze stijging in gemiddelde consumptie ingaan: (1) achtergronden van de veranderingen in 'gewoon' of 'gangbaar drankgebruik' en (2) de effecten van veranderingen in gangbaar drankgebruik op de mate waarin excessief gedronken wordt.

Achtergronden verandering in drankgebruik sinds 1960

De meest gehoorde hypothesen over de na 1960 in Nederland veranderde drinkgewoontes zijn: (1)emancipatie, (2)domesticatie van traditionele drinkgewoonten en (3)nieuwe drinkgewoontes De populairste hypothese van die drie was die van cle emancipatie. ledereen kon zich voorstellen dat heel veel vrouwen en wat minder mannen het historisch gegroeide verschil in drankgebruik tussen mannen en vrouwen onrechtvaardig vonden. Zelden of nooit resulteerde dat in de verwachting dat mannen hun drankgebruik zouden matigen. Verwacht werd dat vrouwen veel meer gingen drinken en mannen ongeveer hetzelfde bleven drinken. Dit zou dan resulteren in een afnemend verschil tussen mannen en vrouwen. Een collega, Rudi Neve, heeft uitgezocht of deze redenering klopte. Het blijkt dat zowel mannen als vrouwen tussen 1960 en 1989 hun consumptie verdrievoudigden.

Gemiddeld aantal glazen alcoholhoudende drank per week van mannen en wrouwen

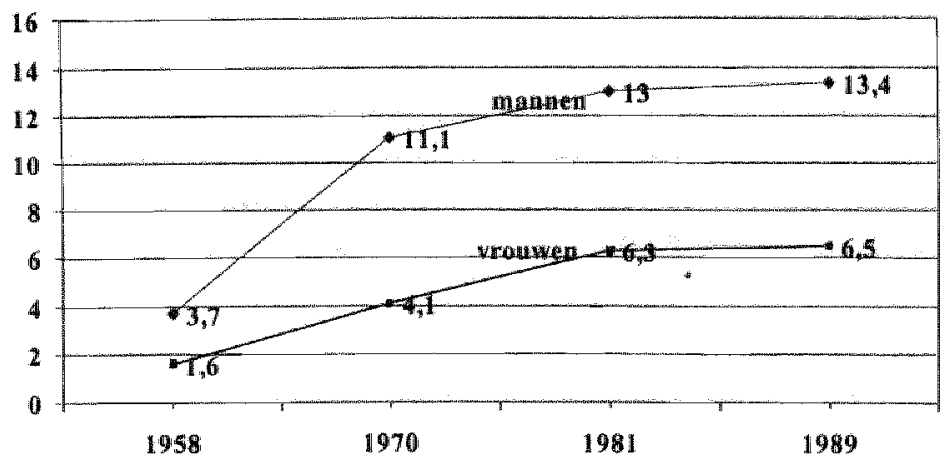


In 1958 dronken mannen gemiddeld 3.7 glazen per week. Dat was ruim 2 maal zoveel ais vrouwen toen dronken: 1.6 glas. In 1989 dronken mannen nog steeds 2 keer zoveel als vrouwen, namelijk ruim 13 glazen per week tegen gemiddeld 6.5 glas bij vrouwen. Het relatieve verschil is dus gelijk gebleven. In glazen uitgedrukt is het verschil tussen mannen en vrouwen zelfs gegroeld van ruim 2 glazen in 1958 tot bijna 7 glazen in 1989 . Kortom, voor de emancipatie hypothese is geen steun te vinden. Hoe zit het met de domesticatie van traditionele drinkgewoonten, dat wil zeggen is het drankgebruik in huiselijke context vooral toegenomen? Goed ciffermatig materiaal daarover ontbreekt. We weten dat voor de $2^{\theta}$ wereldoorlog het drankgebruilk veel sterker geconcentreerd was in publieke drinkgelegenheden. We weten ook dat thans 20 'n $80 \%$ van onze nationale consumptie in huiselijke context wordt genuttigd. Vanaf de jaren zestig was in een groeiend aantal huishoudens in Nederland drank beschikbaar. De man of vrouw kon steeds gemakkelijker beslissen om van een thuissituatie iets bijzonders te maken, door de alcoholhoudende dranken uit de kast te halen. Domesticering en daarmee privatisering van traditionele drinkgewoontes is de trend geweest vanaf de jaren zestig. Terzijde, 1 categorie van de bevolking heeft succesvol vastgehouden aan de ouderwetse manier van drinken: in het cafe. Jongeren drinken $80 \%$ van hun totale consumptie niet thuis maar in publieke drinkgelegenheden. I kom daar nog op terug. Vanaf de jaren zestig vindt daarnaast een nieuwe gewoonte, namelijk wijn drinken, massaal navolging in Nederland. Tot de jaren zestig was, behalve in de mediterrane landen, de wijn consumptie in alle Europese landen bijzonder laag. In Nederland bv. gemiddeld slechts 3.5 fles wijn per jaar oftewel 1 glas per 2 weken. Vanaf de jaren zestig is de wijnconsumptie sterk toegenomen; veel sterker zelfs dan de consumptie van de traditionele dranken: bier en jenever. In Nederland verdrievoudigde de bierconsumptie tussen 1960 en 1990 . Echter de wijnconsumptie verzesvoudigde in die periode. Ook na 1990 is in Nederland het aandeel van wijn in de totale alcoholconsumptie blijven groeien. Met mijn collega Christianne Hupkens heb ik de adoptie en diffusie van nieuwe drinkgewoontes vanaf 1960 in Nederland en andere Europese landen beschreven. Het uitgangs-punt is ontleend aan de theorie van Bourdieu over sociale stratificatie. Die theorie veronderstelt dat groepen die zich willen laten voorstaan op een superieure levensstijl, dat bewijzen door uitheemse, exotische gewoonten in hun leefwijze op te nemen. Deze redenering volgend is te verwachten dat vooral de beter opgeleiden in 
Europese landen uitheemse drinkgewoontes adopteerden. Dit wordt ook bevestigd door ons onderzoek. In de niet-mediterrane landen zijn het vooral de beter opgeleiden -en onder hen weer degenen ouder dan 30 jaar-die wijn drinken en dat nog wel bij maaltijden hetgeen ook een nieuwigheid was. In de mediterrane landen was wijn drinken nu niet iets waarmee je je kon onderscheiden. Als je in de mediterrane landen je wilde laten voorstaan op een meer verfijnde smaak, dan was zoiets exotisch als bier drinken een betere manier. En dat zien we dan ook: de beter opgeleiden in de mediterrane landen drinken vaker bier dan de lager opgeleiden in die landen. De trend in alcohol consumptie in Europa vanaf de jaren zestig wordt dan ook deels verklaard doordat de hoger opgeleiden uitheemse proletarische drinkgewoontes uit andere landen importeerden en aan hun levensstijl toevoegden.

\section{Gevolgen voor prevalentie excessief drankgebruik}

Beide processen, domesticatie van traditionele dranken en adoptie en diffusie van nieuwe dranken, verklaren de achtergrond van de stijging in consumptie in Nederland. Is dit echter allemaal relevant vanuit het perspectief van gezondheid? Het gaat hier toch grotendeels om veranderingen in sociaal drankgebruik? Het kan toch niet zo zijn dat een nieuwe gewoonte als 1 of twee glazen bij het eten iets te maken heeft met verslaving. Noch is het goed voorstelbaar dat de paar biertjes genuttigd voor de t.v. bij de Europa cup-wedstrijden een 'drankprobleem' zijn. Het gebrek aan voorstellingsvermogen op dit punt wordt sterk gevoed door de gedachte dat er een kloof gaapt tussen sociale en excessieve drinkers. Echter, een andere gedachtegang is in principe even plausibel. Als het de trend is om in meer situaties drankgebruik 'gewoon' te vinden, waarom zouden dan matige drinkers niet ook in die situaties mee gaan drinken? Op deze manier kan, zonder dat er iets bijzonders aan de hand is met de drinker, de voorheen matige drinker geleidelijk aan een zware of excessieve drinker zijn geworden.

Om te toetsen welke samenhang er nu is tussen gangbaar drankgebruik in een samenleving en de mate waarin er excessief wordt gedronken moet de relatie tussen de gemiddelde consumptie en het percentage zware of excessieve drinkers geanalyseerd worden. Daarbij wordt de gemiddelde consumptie geïnterpreteerd als indicatief voor wat als 'gewoon' geldt in die samenleving. Nederland tussen 1960 en 1990 is daarbij een goede casus omdat wat als 'gewoon' geldt vanaf 1960 zo sterk is veranderd. 
In onderstaande figuur ziet u de samenhang tussen gemiddelde consumptie en het percentage mannen dat meer dan 21 glazen per week drinkt.

Percentage mannen dat 21 glazen of meer per week drinkt

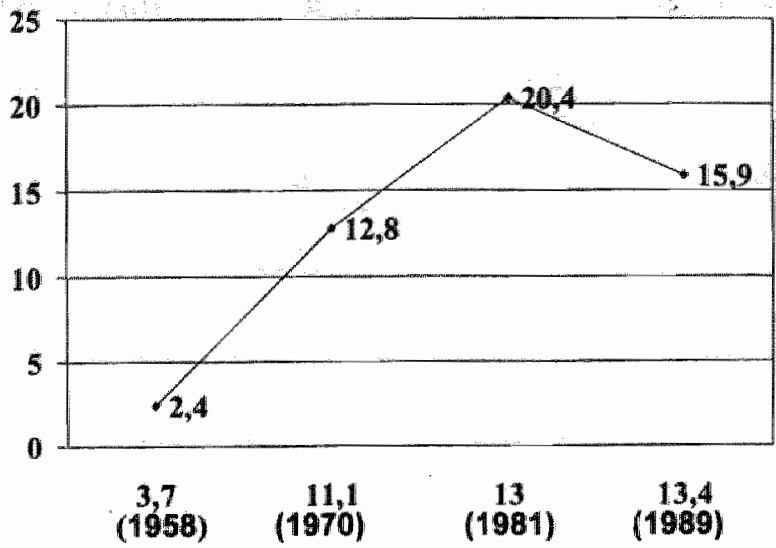

Zou je om een zware drinker te zijn over bijzondere eigenschappen moeten bezitten, zoals in de rekkelijke filosofie veronderstelt wordt, dan kan de gemiddelde consumptie veranderen zonder dat er veel veranderd in het percentage zware drinkers.

Het blijkt echter dat er een heel regelmatige samenhang is: bij stijging van de gemiddelde consumptie stijgt ook het percentage zwaardere drinkers. In 1989 is de gemiddelde consumptie van mannen 13.5 glas per week, ruim 3.5 maal hoger dan de 3.7 glazen in 1958. De prevalentie van zwaarder drankgebruik is in 1989 echter ruim 6.5 maal hoger $(16 \%$ vs $2.4 \%)$ dan in 1958 . De conclusie is dus dat een stijging van 'gewoon' drankgebruik gevonden samengaat met een nog sterkere stijging in prevalentie van zwaarder drankgebruik. Voor een goede interpretatie van deze uitkomst is het volgende van belang:

- de alcohol consumptie is gemeten door mensen te vragen hoeveel ze drinken. We weten echter dat ongeveer de helft van het gebruik onderschat wordt in zelfrapportages. De mensen die zeggen 21 glazen of meer per week te drinken zullen in werkelijkheid minstens 30 glazen per week drinken. 
- Ook bij hogere afkappunten voor 'zwaar' of excessief drankgebruik wordt gevonden dat de stijging in het percentage excessieve drinkers groter is dan de stijging in gemiddelde consumptie.

- de trends in nadelige gevolgen in Nederland bevestigen het verband tussen stijgende gemiddelde consumptie en een stijging in problematisch drankgebruik. Tussen 1970 en 1980 is het aantal mannen opgenomen in algemene ziekenhuizen voor alcoholisme vertienvoudigd (van 2.6 naar 30.9 per 100.000 mannen). Hetzelfde geldt voor opnames met als diagnose alcoholgebruik in combinatie met medicijnen $(0.3$ naar 2.6 per 100.000 ). Het aantal mannen met als diagnose alcoholische levercirrose is in die 10 jaar verdrievoudigd. Voor vrouwen is het patroon bij benadering hetzelfde.

De conclusie dat gangbaar drankgebruik en excessief en problematisch drankgebruik met elkaar samenhangen heeft consequenties voor het preventiebeleid. Een effectief preventiebeleid kan niet zonder maatregelen die drankgebruik ontmoedigen, ook in situaties waarin drankgebruik gewoon gevonden wordt. Voorbeelden van zulke maatregelen zijn een prijsbeleid; een verbod op verkoop van drank bij bv. benzinestations, snackbars, nachtwinkels; beperkende maatregelen voor verkoop van drank in bv. sportkantines en buurthuizen. En natuurlijk behoort effectieve handhaving van de reeds bestaande wetten aangaande leeftijdsgrenzen en niet doorschenken bij dronkenschap ook tot zo'n beleid. Het zijn het soort maatregelen die niet goed passen bij een rekkelijke ideologie. Het wordt gevoeld als ontkenning van de individuelle verantwoordelijkheid voor drinken. Tevens strookt het niet met de gedachte dat het risiko op excessief drankgebruik geconcentreerd is in een relatief kleine groep drinkers en dat daarop het preventiebeleid gericht zou moeten zijn. Deze bezwaren berusten niet op feiten maar moeten toch serieus genomen worden omdat ze obstakels vormen voor steun voor een werkelijk effectief preventiebeleid. De empirische steun voor de relatie tussen gangbaar en excessief drankgebruik, betekent dat een effectief preventiebeleid grotere offers vraagt van sociale drinkers dan in de rekkelijke ideologie voor nodig wordt gehouden. Dit zal ongetwijfeld ook voor de toekomst een punt van discussie blijven. 


\section{Alcoholmisbruilk als collectief verschijnsel}

Wellicht heeft het voorgaande u nog niet echt overtuigd van de relatie tussen gangbaar drankgebruik en excessief en problematisch drankgebruik. Daarom wil ik voor een maatschappelijk geaccepteerde drinksituatie in meer detail bekijken of ${ }_{\text {, conform de }}$ rekkelijke ideologie, misbruik de uitzondering is of juist een collectief verschijnsel. Zijn er gangbare drinksituaties waarin "controleverlies' over drankgebruik de regel is en de veel geprezen verantwoordelijkheid voor eigen drankgebruik de uitzondering? Die zijn er iedere vakantie en ieder weekend weer.

Ik wil dat illustreren met een recent onderzoek onder jongeren die zonder ouders op vakantie gaan. Het is een onderzoek dat ik opgezet heb en dat door Sarah Pos van het Nederlands Instituut voor Gezondheidsbevordering en Zlektepreventie (NIGZ) en mij in een rapport is vastgelegd. $\mathrm{Er}$ is een combinatie van kwantitatieve en kwalitatieve methoden gebruikt. Het kwantitatieve deel bestaat uit ondervraging van steekproeven van jongeren op vakantie in drie kustplaatsen in Nederland en in Valkenburg. Het kwalitatieve gedeelte bestaat uit open interviews met jongeren zelf en met mensen die beroepshalve met deze jongeren in aanraking komen: campingbeheerders, strandwachten, preventiewerkers, politie, horecapersoneel en huisartsen.

Er is wat betreft achtergronden niets bijzonders met deze jongeren aan de hand. De gemiddelde leeftijd is ruim 17 jaar; $3 / 4$ van de jongeren volgt een dagopleiding en $90 \%$ van deze jongeren is samen met anderen op vakantie gegaan.

Wat drinken deze jongeren nu in die twee weken dat ze zonder ouders op stap zijn.

In onderstaande tabel is dat weergegeven voor de verschillende plaatsen waar we steekproeven van jongeren hebben ondervraagd.

Gemiddeld aantal glazen per vakantiedag van jongeren op vakantie zonder ouders

\begin{tabular}{|l|l|l|l|l|}
\hline & Valkenburg & Texel & Terschelling & Noordwijk \\
\hline mannen & 19.5 & 24 & 34 & 26.6 \\
\hline Vrouwen & 4.8 & 10.8 & 13 & 22.2 \\
\hline
\end{tabular}

Brón: Pós, Knibbe,2001

Drie jaar eerder werden overeenkomstige cljfers gevonden voor drankgebruik van jongeren op vakantie. Deze hoeveelheden zijn dus geen uitschieter maar al langere tijd 'normaal' voor wat 
jongeren op vakantie drinken. Er zijn twee typen reacties op de hoeveelheden die dagelijks gedronken worden door deze jongeren: de "waar maak je je druk om" reactie en de hulpeloze reactie. Een illustratie van de 'waat maak je druk om reactie ontleen ik aan een column in de Leeuwarder courant over dit onderzoek.

"Hoe kan dat nou dat jongens op Terschelling gemiddeld per dag 34 glazen bier drinken, vroeg de hoogleraar zich vertwijfeld al. Wel, opnieuw vanuit de luve stoel, omdat ze heel jiverig "s morgens om half elf het eerste pilsje pakken en dan wrolijk doorgaan tot 's nachts half drie. Dat zijn vijftien uren klokklok, oftewoleen glas per 26 minuten. Dat is technisch gesproken een lachertje voor een gezonde Hollandse jongen mits hij in redelijke conditie op vakantie ging en voldoende frikadellen speciaal naar binnen schuift als bodem." (Leeuwarder Courant, 29-03-01).

En inderdaad, een glas per 26 minuten is niet zo bijzonder. In een observatiestudie van len van de Goor en mij in jongerencafe's blijkt in gewone weekenden het gemiddeld tempo van de jongere mannen zelfs nog hoger te liggen: zo'n 20 minuten per glas. Ook de jongeren zelf vinden het normaal. Twee citaten uit de open interviews om dat te boekstaven:

"Ja hier beginnen we eerder en we gaan later naar huis omdat ik geen tijd mee heb"

"Ja, als ik uit bed kom begin ik met drinken totdat ik naar bed ga" De reacties van de mensen die beroepshalve in aanraking komen met deze jongeren zijn echter op, een uitzondering na, meer bezorgd. De uitzondering is Terschelling waar drie van de zeven geînterviewde sleutelfiguren stellen het excessieve drankgebruik van jongeren helemaal niet zo'n probleem te vinden. Een citaat: " $k$ vind het geen probleem, laat ze maar gaan. Het is vakantie. Als ze zeven dagen hier zijn. Als ze het hele jaar zo lopen te tanken, ja dan is het wel een probleem, dan heb je zelf ook een probleem, maar dat doen ze niet".

Echter op hetzelfde Terschelling meldt een kampwacht het volgende in een interview. "Ik had vier vrouwen die door pure alcoholvergiftiging helemaal hysterisch werden. Nou daar heb ik gewoon de hele tijd bijgezeten. Laten braken, rustig houden, op in blijven praten, koude kompressen leggen, dat is in feite het enige dat je kunt doen.(..) De mannen kruipen gewoon in hun tent en kotsen de tent onder en dat zie je niet. Maar de vrouwen worden gewoon hysterisch als ze overmatig drank hebben gebruikt." En op het naburige eiland Texel, de campingbeheerder: 
¿...drie gevallen van coma door drank meegemaakt(...)Tot voor kort was in principe de aanpak om ze gewoon hier te houden en onder bewaking te stellen en om ze vast te zelten op een brancard en dergelijke om te zorgen dat ze veilig de nacht doorkomen. Maar dat doen we niet meer, we hebben besloten om ze gewoon af te laten voeren" (naar het ziekenhuis in Den Helder). Deze meldingen zijn het topje van de ijsberg zijn. De sleutelfiguren zelf wijzen er op dat het veel vaker voorkomt dan zij het van nabij meemaken.

Toevallen of insulten behoren ook tot de criteria die in onderzoek gebruikt worden om alcoholmisbruik en verslaving vast te stellen. Ik wil een aantal van de klinische criteria voor misbruik en verslaving wat systematischer toepassen op het drankgebruik van deze jongeren. Het hiernavolgende is gebaseerd op de open interviews met jongeren zelf en met de sleutelfiguren die beroepshalve in aanraking komen met deze jongeren.

* Twaalf glazen of meer gemiddeld per dag drinken is een van de criteria. Bij mannen ligt de gemiddelde dagelijkse consumptie ruim boven de 12 zoals u heeft gezien. Bij vrouwen dicht bij de 12 gllazen per dag.

* Ongeval of ongeluk onder invloed van alcohol: komen vaak voor zowel volgens jongeren zelf als volgens de huisartsen. Doordrinken ondanks een ongeval of ongeluk is een ander criterium dat op verslaving wijst. Voor jongeren is een ongeluk of ongeval geen reden de volgende dag niet weer te drinken.

* Drankgiebruilk in situaties met verhoogd risico: komen veel voor; met name fietsen, maar ook bier of andere alcoholische dranken als dorstlesser op zonnige dagen leidt tot ongelukken.

* Trillende benen en/of handen, misselijkheid, zwak voelen: komen zeer vaak voor. En ja, natuurlijk drinken jongeren om van de kater, trillende handen af te komen. In de interviews met jongeren wordt dat gemeld. Het wordt bevestigd door sleutelfiguren, bv. de campingbeheerders die meldt dat er om zeven uur "s morgen al mensen bij de campingwinkel staan voor bier.

Niet genoemd bij de criteria voor verslaving, wel door de sleutelfiguren, is de algehele verslechtering in lichamelijk en psychologisch functioneren. Een citaat van een sleutelfiguur op Texel: "En je merkt dus als we naar de boot zouden gaan, dat ze helemaal op en uitgeblust zijn, ze nemen ook nog wat af, want het is natuurlijk alleen maar drinken, ze eten slecht en je ziet dus op de boot van die bleke doodmoeie mensjes, ze zijn heel erg vermoeid, 
helemaal over hun grens heengegaan. Ze worden ook vergeetachtig, geirriteerd (...)Dat korte termingeheugen van die jongeren is vreselijk gestoord. Dat zie je heel goed, zeker als je jongeren een tijdje heb leren kennen, hoe ze eerst waren en op het laatst..."

Volgens klinische relevante criteria is bij een heel groot deel van de mannen en een minder groot, maar nog steeds aanzienlijk deel van de vrouwen sprake van misbruik en verslaving. Wat moet je nu met zo'n conclusie? Die jongeren hulpverleners op hun dak sturen? Lijkt me niet. Je verbazen over de mogelijkheden tot spontaan herstel van verslaving na afloop van de vakantie bij deze jongeren? Ook niet, alleen al omdat ook in gewone weekenden jongeren vergelijkbare hoeveelheden drinken. Echt verbazingwekkend is dat alle omstanders er zo hulpeloos bij staan te kijken. Dat geldt voor de horeca exploitanten, de ouders, de campingbeheerders, de politie en de gemeentebesturen. Die hulpeloosheid heeft alles te maken met de blinde vlek in de rekkelijke ideologie voor de verandering van spelregels: niet verantwoording nemen, maar juist even geen verantwoording hoeven te nemen is de conventie in drinksituaties.

\section{Drinksituaties als time out'}

Om dat verder uit te werken wil ik dieper ingaan op de van oorsprong voornaamste vorm van ritualisering van drankgebruik in onze samenleving: die van een collectief gepraktiseerde gewoonte in openbare (bv. cafés) of semi-openbare (bv. feesten) setting Jongeren zijn in onze samenleving, maar ook in andere Europese en Amerikaanse landen degenen die het meest energiek deze oude vorm van drankgebruik praktiseren. Het is een drinksituatie die in een al oudere studie van Mac Andrew en Edgerton getypeerd wordt als een 'time-out'-situatie. Bij McAndrew en Edgerton stond het begrip centraal in de verklaring van de cultureel variabele samenhang tussen alcohol en agressie. Ik wil het iets breder bekijken door het contrast aan te geven tussen de gedragsregels in het gewone alledaagse leven en in time out situaties, bv. bij uitgaan in het weekend of op vakantie met vrienden. Het verschil is op meerdere niveaus weer te geven. Op individueel niveau geldt in het alledaags leven de regel dat sociale verplichtingen die je hebt aan bv. huisgenoten, school, werk, verenigingsleven voorrang hebben in je tijdsbesteding. In een time out situatie is de regel dat je vrijgesteld bent van die verplichtingen. Je mag vrijer en spontaner zijn en niet uitgestelde, maar 
directe bevrediging van behoeftes is de leidraad voor het handelen. Op groepsniveau is de regel in het alledaags leven dat mensen elkaar aanvullen met hun activiteiten. Het is een meer organische solidariteit die de omgangsregels bepaalt. Bij handhaving van deze regels is wel sprake van strukturele verschillen in macht en status tussen de betrokkenen. In time-out situaties is er sprake van mechanische solidariteit. Identificatie met de groep en niet of minder differentiatie binnen de groep is de regel. Tussen groepsleden zijin er well verschillen in status- en macht. Echter ze zijn minder struktureel en je kan je er gemakkelijk aan onttrekken. Op maatschappelijk niveau is in het alledaagse leven de regel dat je je houdt aan wat moet en hoort en wordt je ter verantwoording geroepen als je in gebreke blijft. In een time-out situatie ligt het primaat voor het moment bij wat kan en mag en is de directe bevrediging die dat schenkt voldoende legitimatie. Bij aanvang van een collectieve drinksituatie zullen de regels voor het alledaagse functioneren ook nog enigszins gelden. Echter, naarmate er meer drank doorheen is gegaan zal de aanspraak op vrijheid van alledaagse, redelijke overwegingen, identificatie met de groep en kapitalisatie van wat mag en kan toenemen.

Een analyse in termen van regels die in time out situaties gelden geeft aan wat er aan preventie moet gebeuren om de kans op ontsporing te minimaliseren. Een situatie die mensen uitnodigt afstand te nemen van hun verantwoordelijkheden, vereist dat anderen in die situatie spelregels stellen en handhaven om te voorkomen dat vrijheden ontsporen in misbruik, ongelukken en agressie. Het is nuttig om dit simpele principe eens te stellen naast wat er feitelijk op het gebied van handhaven van spelregels gebeurt. Ik begin met de wettelijke vastgestelde maatregelen. In de eerder genoemde studie is de handhaving van de wettelijke leeftijdsgrenzen voor verkoop van alcoholische drank nagegaan, door een vijftienjarige in een reeks winkels, snackbars en uitgaansgelegenheden alcoholische drank te laten bestellen. Op een uitzondering na, werd hem overal zonder iets te vragen, alcoholische drank verstrekt. Voor het wettelijke verbod op doorschenken bij dronkenschap geldt hetzelfde: het wordt nergens systematisch gehandhaafd. Als wettelijke maatregelen al niet gehandhaafd worden, dan kunt u zich voorstellen hoe het is met aanvullende maatregelen ter voorkoming van excessief drankgebruik. De houding van de betrokken partijen, of het nu een gemeentebestuur, politieman, campingbeheerder of kastelein is, is er een van hulpeloosheid al dan niet gelardeerd met een verhaal over de verdorvenheid van de tegenwoordige jeugd. Zolang 
het primaat van de eigen verantwoordelijkheid van de drinker als uitgangspunt genomen wordt zal die hulpeloosheid ook bijwen bestaan. Effectief preventiebeleid in deze context kan niet zonder dat je met alle partijen die met deze drinkende jongeren te maken krijgen, duidelijke afspraken maakt over hoe overmatig drankgebruik te voorkomen. Anders gezegd, een community interventie, waarin andere betrokkenen dan de jongeren zelf duidelijke regels stellen over beschikbaarheid van dranken en grenzen tussen toelaatbaar en ontoelaatbaar gedrag is noodzakelijk voor effectieve preventie. Hiervoor is bij de betreffende partijen een ideologische omslag nodig.

Mijn inschatting is dat de bereidheid om grenzen te stellen aan het drinkgedrag tijdens vakanties en bij uitgaan in het weekend groeiende is. Ten dele heeft dat te maken met wat ik maar even het Tjoelker effect noem. De schrik over het geweld waartoe gewone mensen in staat blijken te zijn na een avondje stappen is flink toegenomen. Het heeft ook te maken met het inmiddels wat meer aandacht krijgende feit dat alcoholgerelateerde ongevallen en ongelukken de belangrijkste doodsoorzaak zijn bij jongeren. Voor een community interventie is behalve consensus tussen de betrokken partijen dat ze er lets aan moeten doen, nog iets anders nodig. De juiste instrumenten moeten ook ontwikkeld worden. Horecapersoneel zal getraind moeten worden in herkennen van en omgaan met dronken mensen. Handhaving leeftijdsgrenzen zal serieus aangepakt moeten worden. De bevoegdheden van gemeenten om de verkoop van alcohol te reguleren, die nu op vrijwel exclusief gebruikt worden bij festivals, kan veel gerichter gebruikt worden om excessief gebruik te voorkomen. Echter, ook bij de jongeren zelf dient een proces op gang gebracht te worden waardoor ze in mindere mate blindelings de vrijheid die een time-out situatie biedt, invullen met overmatig drankgebruik. Het dient een interventie te zijn gericht op effectieve ontkrachting van de overspannen verwachtingen van jongeren over de gunstige effecten van drankgebruik op -met name- hun sociaal functioneren en seksuele aantrekkelijkheid. Een belangrijke aanvullende voorwaarde is echter dat deze interventie uitgevoerd wordt in of zeer nabij actuele drinksituatles zelf. Immers, de time-out situatie impliceert dat jongeren de vrijheid zullen nemen alle wijsheid over drankgebruik, die ze bv. via voorlichting op school of via massa media hebben verworven, aan de kant mogen zetten zodra ze beginnen met drinken. Het is duidelijk dat er op dit gebied innovatief gewerkt moet worden om enig effect van preventieve inspanningen te mogen 
verwachten. Ik verwacht, samen met anderen, aan deze innovatie de komende jaren te zullen bijdragen.

\section{Dankwoord}

I $\mathrm{k}$ ben aan het einde gekomen van het inhoudelijk deel. Er is veel meer te zeggen, echter de tijd is beperkt. Ik sluit af met enkele woorden van dank. Op professioneel gebied geldt dat in de eerste plaats de hoogleraren Riet Drop en Henk Garretsen. Met beiden heb ik vanaf de aanvang van mijn academische loopbaan nauw samengewerkt. Met Henk Garretsen deelde lk in 1980 de positie van beginnend onderzoeker. Ruim 20 jaar duurt onze samenwerking nu. De collegialiteit en hartelijkheid die er is doen uitzien naar de samenwerking in de komende jaren. Riet Drop was mijn promotor en vervolgens mentor met name op het terrein van alle facultaire besognes waarmee een docent te maken krijgt. Ik heb veel van haar geleerd en ben haar daar dankbaar voor. Professor dr. Hans Philipsen will ik bedanken voor de flitsende inzichten die hij me af en toe toevertrouwde. Mijn collega's bij Medische Sociologie wil ik bedanken. Ook in een matrix organisatie heeft een mens een professionele thuisbasis nodig. Zij zijn dat voor mij geweest. Een bijzonder woord van dank geldt Marjoke Arkenbout voor de ondersteuning die ze me al jarenlang biedt. In de loop der jaren heb ik ook intensief en vruchtbaar samengewerkt met collega"s uit andere vakgroepen. Ik heb dat leuk en inspirerend gevonden en zal in de toekomst samenwerking blijven zoeken met andere disciplines. Ik ben in de luxe positie er enige tijd geleden een hele club collega's te hebben bijgekregen, namelijk de medewerkers van het IVO in Rotterdam. Ook hen will ik bedanken voor de samenwerking.

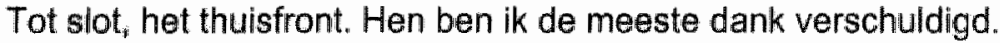
Overigens niet omdat ze me dagelijks aanmoedigden om weer eens aan een artikel of college te werken. Bonne, Robin, Mare, Kim en Annemie, mijn dankbaarheid jegens jullie is geen onderwerp van een rede, die blifft hier dus verder ongezegd. Ik heb gezegd. 


\section{Literatuur}

Bourdieu P(1986) Distinction. A social critique of the judgment of taste. London, Roultedge, Kegan Paul

Coumans $A M$. Neve RJM, Mheen H ven de(2000) Het proces van marginalisering en verharding in de drugscene van Parksatd Limburg. IVO, Rottendam

Edwards G et al (1995) Alcohol Pilicy and the Public Good. Oxford University Press, Oxtord

European Monitoring Centre for Drugs and Drug Addiction (1998) Annual report on the state of the drug problem in the European Union

EMCDDA Scientific Reportl (2001) Coordination of the implementation of the EMCDDA standard guidelines on the drug-related deaths in the EU Member States and the collection and analysis of information on drug related deaths. Lissabon

Grund JPC (1993) Drug use as a social ritual. Functionality, symbollsm and determinants of self-regulation. WO reeks 4 , Rotterdam

Hoogendoorm D(1983)Opnamen in zlekenhuizen wegens overmalig drankgebruik. Ned.T.Geneesk, $127,1011-7$

Hupkens CLH, Knibbe RA, Drop MJ(1993) Alcohol consumption in the European community: uniformity and diversity in drinking patterns. Addiction, 88, 1391-1404

Junger S(1998) Medisch-sociale hulpverlening aan methadonclienten in de Neder landse-Duitse grensregio. Universiteit Maastricht

Knibbe RA (1998) Measuring Drinking Context. Alcoholism; Clinical and Experimental research, p15s-20s

Knibbe RA, Goor I wan de, Drop MJ(1993) Contextual influences on young people's drinking rates in public drinking places: an observational study. Addiction Research $1,269-278$

Mac Andrew C., Edgerton, RB(1969) Drunken comportment: a social explanation. Chicrago, Aldine

Neve R(1998) The life course, gender and alcohol use. Universiteit Maastricht

Pos $\mathrm{S}_{3}$ Kribbe RA (2001) Alle dagten feest? Een kwalitatives studie naar omgevingsinvloeden op hei alcoholgebruik van jongeren op vakantie. NIGZ/Uniwersiteil Maastrich, Woerden, Maastricht

Room R(1999): The rhetoric of international drug control. Substance Use and Misuse, $34,1689-1707$

Room R (2001) Intoxication and bad behaviour: understanding cultural differences in the link. Soc, Sc.Med. 53,189-198

Smeets RMW, Dingemans PMAJ(1993) Composite Inbternational Diagnostic Interview (CIDI), wersion 1.1. Amsterdam NHO 